\title{
FORMULASI SEDIAAN HAND SANITIZER DARI EKSTRAK BIJI PANGI (Pangium edule REINW)
}

\author{
Formulation of Hand Sanitizer from Pangi Seed Extract (Pangium edule Reinw)
}

\author{
Rohana, Hendra Stevani*, Ratnasari Dewi \\ Jurusan Farmasi Poltekkes Kemenkes Makassar \\ *Email: hendra@poltekkes-mks.ac.id
}

DOI: https://doi.org/10.32382/mf.v15i2.1133

\begin{abstract}
Pangi seeds contain flavonoids and are proven to have an antibacterial effect, though they are still used in a traditional way within the community. There is a need for it to be developed into a formula that is more practical and durable, such as Hand sanitizer. The purpose of this research is to formulate the preparation of Hand sanitizer from Pangi Seed Extract (Pangium edule Reinw). The seeds were extracted by maceration using distilled water and made into Hand sanitizer gel using TEA, Glycerin, Nipagin, and Aquades. The variations in the concentration of carbohydrate and sodium CMC base were 0.25\%: 2\%; 0.5\%: 3\%; 0.75\%: 4\%. The results showed that all three preparations before and after storage were homogeneous, pale yellow, and odorless. Besides, the viscosity of the gel ranges from 242471-4151 cP, but changes after storage. However, gel pH ranges from 5-6 and does not change after storage. In all the three preparations, no synergy occurred, and their spreadability ranged from $5 \mathrm{~cm}$ to $7.5 \mathrm{~cm}$, undergoing changes after storage. This study concludes that the Pangi Seed extract might be formulated into a gel preparation with a Carbopol: Sodium CMC base concentration of $0.5 \%: 3 \%$ and meets all quality requirements.
\end{abstract}

Keywords: Pangi Seed, Gel, Carbopol, Na. CMC, Hand sanitizer.

\begin{abstract}
ABSTRAK
Biji Pangi mengandung flavonoid serta terbukti memiliki efek antibakteri, namun penggunaannya oleh masyarakat masih secara tradisional sehingga perlu dikembangkan menjadi formula yang lebih praktis digunakan, dan lebih tahan lama seperti Hand sanitizer. Tujuan penelitian untuk memformulasikan sediaan Hand sanitizer dari ekstrak Biji Pangi (Pangium edule Reinw). Biji Pangi diekstraksi dengan cara maserasi menggunakan pelarut akuades dan dibuat menjadi gel Hand sanitizer menggunakan TEA, Gliserin, Nipagin, Akuades serta variasi konsentrasi basis Karbopol dan Natrium CMC yaitu 0,25\%:2\% ; 0,5\%:3\% ; 0,75\%:4\%. Hasil penelitian menunjukkan ketiga sediaan sebelum dan setelah penyimpanan homogen, berwarna kuning pucat, dan tidak berbau. Kekentalan gel berkisar`2471-4151 cP, tapi mengalami perubahan setelah penyimpanan. pH gel berkisar 5-6, tidak berubah setelah penyimpanan. Tidak terjadi sineresi pada ketiga sediaan. Daya sebar ketiga sediaan berkisar $5 \mathrm{~cm}-7,5 \mathrm{~cm}$, mengalami perubahan setelah penyimpanan. Dari penelitian ini dapat disimpulkan bahwa ekstrak Biji Pangi dapat diformulasikan menjadi sediaan gel dengan konsentrasi basis Karbopol: Natrium CMC yaitu 0,5\%:3\% dan memenuhi semua persyaratan mutu.
\end{abstract}

Kata Kunci : Biji Pangi, Gel, Karbopol, Na. CMC, Hand sanitizer.

\section{PENDAHULUAN}

Diare adalah kejadian buang air besar yang melebihi kebiasaan ditandai dengan feses yang lebih encer. Profil Kesehatan Dasar Tahun 2018 oleh kementerian kesehatan menunjukan pravalensi kejadian diare di provinsi sulavesi selatan mencapai $15 \%$ diatas rata-rata pravalensi kejadian diare di Indonesia yang mencapai
12,5\%.(Kementerian Kesehatan Republik Indonesia 2018) Adapun salah satu cara mudah untuk mencegah kematian dan penyakit yang berhubungan dengan diare adalah cuci tangan. Menurut data WHO (2014), mencuci tangan dengan sabun dapat mengurangi $40 \%$ risiko diare dan $20 \%$ risiko infeksi saluran pernapasan akut, 
termasuk pneumonia.(World Health Organization. Patient Safety n.d.)

Seiring dengan perkembangan zaman, masyarakat cenderung menggunakan produkproduk instan yang serba cepat dan praktis dalam beraktivitas. Salah satu produk yang praktis dan efisien dalam membersihkan tangan yaitu produk berupa gel antiseptik tangan yang dapat digunakan tanpa memerlukan air atau dikenal dengan nama hand sanitizer. Hand sanitizer merupakan zat antiseptik yang didalamnya terdapat alkohol dengan persentase 60-95\%. Menurut Food and Drug Administration (FDA), Hand sanitizer dapat menghilangkan kuman kurang dari 30 detik.

Salah satu tumbuhan yang dapat digunakan sebagai gel hand sanitizer ialah Pangi (Pangium edule Reinw). Bagian Pangi yang digunakan yaitu daging Biji Pangi. Saat ini Biji Pangi tidak digunakan secara maksimal, kebanyakan masyarakat menggunakan Biji Pangi sebagai bumbu masakan. Untuk dapat memaksimalkan penggunaannya terutama dalam dunia kesehatan, Biji Pangi dapat dibuat dalam bentuk formula gel antiseptik tangan. Biji Pangi mengandung senyawa golongan flavonoid yang berfungsi sebagai anti-bakteri diantaranya asam sianida, asam hidrokarpat, asam khaulmograt, asam gorlat dan tannin.(Christine Makagansa, Christine F. Mamuaja 2015)

Berdasarkan penelitian tentang kandungan fitokimia dan aktivitas anti-bakteri ekstrak Biji Pangi yang dilakukan Christine Makagansa, dkk (2015) menunjukkan uji kuat penghambatan ekstrak air pangi terhadap bakteri Staphylococcus aureus pada konsentrasi $8 \%$ adalah sangat kuat dan pada konsentrasi $6 \%, 4 \%$ dan $2 \%$ adalah kuat. Efek anti bakteri dari Biji Pangi diduga karena kandungan dari fenolnya.(Christine Makagansa, Christine F. Mamuaja 2015)

Basis yang sering digunakan dalam pembuatan gel antara lain Karbopol dan Natrium CMC. Keuntungan penggunaan Natrium CMC sebagai basis gel diantaranya adalah memberikan viskositas stabil pada sediaan. Namun, penggunaan Natrium CMC sebagai basis gel dapat membuat gel menjadi tidak jernih karena menghasilkan dispersi koloid dalam air yang ditandai munculnya bintikbintik dalam gel.(Rowe et al. 2009) Penambahan basis gel berupa karbopol diharapkan dapat memperbaiki kekurangan tersebut, sehingga gel yang dihasilkan menjadi jernih dan diharapkan memiliki daya sebar yang baik. Metode yang dapat digunakan untuk mendapatkan kombinasi karbopol dan Natrium CMC yang menghasilkan formula optimal adalah SLD (Simplex Lattice Design).

Berdasarkan hal-hal di atas, peneliti tertarik untuk membuat sediaan gel Hand sanitizer yang mengandung ekstrak Biji Pangi dengan menggunakan kombinasi basis Karbopol dan Natrium CMC dengan metode simplex lattice design dan menguji stabilitas mutu fisik sediaan gel hand sanitizer dari ekstrak Biji Pangi (Pangium edule Reinw).

\section{METODE}

\section{Pendekatan dan Jenis Penelitian}

Pendekatan dan jenis penelitian adalah Penelitian ini menggunakan metode eksperimen laboratorium dengan desain pre \& post test untuk memformulasikan sediaan gel antiseptik tangan dari ekstrak Biji Pangi (Pangium edule Reinw) serta menguji stabilitas dan mutu fisik sediaan.

\section{Lokasi dan Waktu Penelitian}

Penelitian ini dilakukan pada bulan April sampai Mei 2019 di Laboratorium Teknologi Farmasi Poltekkes Kemenkes Makassar Jurusan Farmasi.

\section{Populasi dan Sampel penelitian}

Sampel dalam penelitian ini adalah gel antiseptik tangan dari ekstrak Biji Pangi (Pangium edule Reinw).

\section{Penyiapan Tanaman Pangi Identifikasi Tanaman Pangi}

Sampel diidentifikasi berdasarkan tampilan morfologisnya dari tanaman Pangi.

\section{Pengambilan Biji Pangi}

Sampel Biji Pangi (Pangium edule Reinw) di ambil dari Kec. Jolle, Kab. Watansoppeng. Biji yang diambil adalah biji putih muda yang masih segar (belum matang) dan belum berjamur.

\section{Pengolahan Sampel}

Buah Pangi yang belum matang, diambil bijinya, kemudian dibersihkan dari buah yang masih menempel, dicuci bersih lalu direbus pada suhu $80^{\circ} \mathrm{C}$ selama 2-3 jam. Setelah itu, Biji Pangi dikeluarkan dengan cara memecahkan kulit Biji Pangi dan selanjutnya ditampung pada wadah plastik. Biji Pangi dicuci bersih kemudian diperkecil ukurannya untuk memudahkan dalam pengeringan. Biji yang sudah diperkecil ukurannya kemudian diletakkan pada wadah plastik yang 
berlubang dan dicuci pada air mengalir sampai air rendaman Biji Pangi benar-benar jernih. Kemudian irisan Biji Pangi ini dikeringkan pada suhu ruang selama 5 hari dengan bantuan kipas angin. Setelah kering, Biji Pangi di serbukkan, kemudian diayak dengan menggunakan ayakan 80 mesh untuk mendapatkan serbuk yang seragam. Setelah itu disimpan pada wadah tertutup sebelum diekstraksi.

\section{Ekstraksi Sampel Penelitian}

Ekstrak Biji Pangi dibuat dengan cara maserasi menggunakan aquadest. Sebanyak $150 \mathrm{~g}$ serbuk simplisia Biji Pangi dimasukkan kedalam Erlenmeyer, kemudian direndam dengan akuades $600 \mathrm{ml}$, diaduk, ditutup dengan aluminium foil dan dimaserasi selama 24 jam. Setelah dimaserasi selama 24 jam, disaring untuk memisahkan filtrat dan ampasnya, kemudian disentrifus filtratnya selama 15 menit sehingga diperoleh ekstrak kental akuades Biji Pangi. (Fransin Mamuaja and Lumoindong 2017)

\section{Pembuatan Sediaan Gel Rancangan Formula.}

Rancangan Formula dapat dilihat di Tabel 1.

Tabel 1. Rancangan Formula

\begin{tabular}{cccccc}
\hline Nama Bahan & Kegunaan & \multicolumn{3}{c}{ Sediaan Gel (g) } & \multirow{2}{*}{ Range (\%) } \\
\cline { 3 - 5 } & & F1 & F2 & F3 & \\
\hline Ekstrak akuades Biji Pangi & Zat aktif & 8 & 8 & 8 & $4-8$ \\
Karbopol & Basis & 0,5 & 0,75 & 1 & $0,5-1$ \\
Na. CMC & Basis & 3 & 4 & 5 & $3-6$ \\
TEA & Pengalkali & 3 & 3 & 3 & $2-4$ \\
Gliserin & Pelembab & 15 & 15 & 15 & $10-20$ \\
Nipagin & Pengawet & 0,15 & 0,15 & 0,15 & $0,02-0,3$ \\
Oleum citrus & Pewangi & 0,25 & 0,25 & 0,25 & $0,2-0,3$ \\
Air suling hingga & Pelarut & 100 & 100 & 100 & - \\
\hline
\end{tabular}

\section{Pembuatan Gel}

Sejumlah nipagin dilarutkan dalam air panas, kemudian larutan nipagin digunakan untuk mengembangkan Na.CMC, Setelah LarutanNa.CMC megembang kemudian ditambahkan larutan karbopol dalam air dingin kemudian dihomogenkan, hingga terbentuk basis gel (Campuran I). Ekstrak Akuades Biji Pangi ditambahkan TEA dan Gliserin, dihomogenkan (Campuran II), lalu Campuran I tadi dimasukkan kedalam Campuran II. Setelah itu, ditambahkan Oleum Citrus.

\section{Uji Stabilitas}

Uji Stabilitas sediaan gel dilakukan dengan penyimpanan dipercepat. Uji cycling test ini dilakukan sebanyak 6 siklus, dimana tiap siklus sediaan gel disimpan pada suhu $\pm 4^{\circ} \mathrm{C}$ selma 24 jam dan ditempatkan pada suhu $\pm 40^{\circ} \mathrm{C}$ selama 24 jam. ((Ali, Stevani, and Rachmawaty 2019))

\section{Evaluasi Mutu Fisik}

Evaluasi mutu fisik sediaan gel antiseptik tangan dilakukan sebelum dan sesudah pengujian dipercepat gel yang meliputi:

\section{Pengamatan organoleptis}

Sediaan Gel yang telah diformulasi dilakukan pengamatan secara fisik meliputi konsistensi / bentuk, bau, dan warna.Gel biasanya jernih dengan konsistensi setengah padat. (Ali, Stevani, and Rachmawaty 2019)

\section{Uji Viskositas}

Pengukuran viskositas dilakukan dengan menempatkan sejumlah sampel dalam viscometer Brookfield DV-E. Ukuran spindle dan kecepatan putaran yang akan digunakan diatur, dan selanjutnya alat dinyalakan dan viskositas dari sediaan gel. Persyaratan viskositas yang baik yaitu 2000-4000 cP (Ali, Stevani, and Rachmawaty 2019) 


\section{Uji Homogenitas}

Pengujian homogenitas dilakukan dengan cara sampel gel dioleskan pada sekeping kaca atau bahan transparan lain yang cocok, sediaan harus menunjukkan susunan yang homogen dan tidak terlihat adanya butiran kasar. (Ali, Stevani, and Rachmawaty 2019)

\section{Pengukuran pH}

Uji pH dilakukan untuk melihat tingkat keasaman sediaan gel untuk menjamin sediaan gel tidak menyebabkan iritasi pada kulit $\mathrm{pH}$ sediaan yang memenuhi kriteria $\mathrm{pH}$ kulit yaitu dalam interval 4,5-6,5 menggunakan kertas indikator $\mathrm{pH}$. (Ali, Stevani, and Rachmawaty 2019)

\section{Uji Sineresis}

Sineresis yang terjadi selama penyimpanan diamati dengan menyimpan gel pada suhu $\pm 10^{\circ} \mathrm{C}$ selama 24,48 dan 72 jam.Masingmasing gel ditempatkan pada cawan untuk menampung air yang dibebaskan dari dalam gel selama penyimpanan.Sineresis dihitung dengan mengukur kehilangan berat selama penyimpanan lalu dibandingkan dengan berat awal gel.(Ali, Stevani, and Rachmawaty 2019)

\section{Pengukuran daya sebar}

Pengukuran daya sebar dilakukan untuk menjamin pemerataan gel saat diaplikasikan pada kulit. Gel ditimbang sebanyak 0,5 gram kemudian diletakkan ditengah kaca bulat berskala. Di atas gel diletakkan kaca bulat lain atau bahan transparan lain dan pemberat sehingga berat kaca bulat dan pemberat 150 gram, didiamkan selama 1 menit, kemudian dicatat diameter penyebarannya. Daya sebar gel yang baik antara 5-7 cm. (Ali, Stevani, and Rachmawaty 2019)

\section{Pengumpulan Data}

Data yang dikumpulkan berupa data primer dari hasil uji mutu fisik sediaan gel hand sanitizer yaitu pengamatan organoleptis, uji homogenitas, uji sineresis, pengukuran $\mathrm{pH}$, dan pengukuran daya sebar menggunakan metode stabilitas dipercepat sebelum dan sesudah penyimpanan.

\section{Analisis Data}

Data yang telah diperoleh kemudian
dianalisa pendekatan teoritis membandingkan antara hasil uji mutu fisik sediaan gel hand sanitizer yaitu pengamatan organoleptis, uji homogenitas, uji sineresis, pengukuran $\mathrm{pH}$, dan pengukuran daya sebar menggunakan metode stabilitas dipercepat dengan persyaratan yang ditetapkan selanjutnya dibahas dan ditarik suatu kesimpulan.

\section{HASIL}

Formula yang digunakan

Formula yang digunakan dalam penelitian ini dilihat pada tabel 2

Tabel 2. Formula sediaan gel dari ekstrak BIJI PANGI (Pangium edule)

\begin{tabular}{|c|c|c|c|c|}
\hline \multirow[t]{2}{*}{ Nama zat } & \multirow[t]{2}{*}{ Kegunaan } & \multicolumn{3}{|c|}{$\begin{array}{c}\text { Formula hand sanitizer } \\
(\% \text { b/b })\end{array}$} \\
\hline & & F1 & F2 & F3 \\
\hline Ekstrak Akuades Biji Pangi & Zat Aktif & 8 & 8 & 8 \\
\hline Karbopol & Basis & 0,25 & 0,5 & 0,75 \\
\hline Natrium CMC & Basis & 2 & 3 & 4 \\
\hline TEA & Pengalkali & 3 & 3 & 3 \\
\hline Gliserin & Pelembab & 15 & 15 & 15 \\
\hline Nipagin & Pengawet & 0,15 & 0,15 & 0,15 \\
\hline Air Suling & Pelarut & ad 100 & ad 100 & ad 100 \\
\hline
\end{tabular}


Hasil Pengujian Fisik dan Stabilitas

Hasil Pengujian Fisik dan Stabilitas dapat dilihat pada tabel 3 s/d 8

Tabel 3. Hasil pengamatan organoleptis sediaan hand sanitizer sebelum dan sesudah uji stabilitas dipercepat selama 6 siklus menggunakan alat climatic chamber.

\begin{tabular}{|c|c|c|c|c|c|c|c|}
\hline \multirow{3}{*}{$\begin{array}{c}\text { (Karbopol : } \\
\text { Na.CMC) }\end{array}$} & \multicolumn{6}{|c|}{ Organoleptis } & \multirow{3}{*}{ Kesimpulan } \\
\hline & \multicolumn{3}{|c|}{ Sebelum pengujian } & \multicolumn{3}{|c|}{ Sesudah Pengujian } & \\
\hline & Konsistensi & Warna & $\mathrm{Bau}$ & Konsistensi & Warna & $\mathrm{Bau}$ & \\
\hline $\begin{array}{c}\text { Formula I } \\
(0,25: 2)\end{array}$ & Kental & $\begin{array}{c}\text { Kuning } \\
\text { pucat }\end{array}$ & $\begin{array}{c}\text { Tidak } \\
\text { berbau }\end{array}$ & $\begin{array}{c}\text { Agak } \\
\text { kental }\end{array}$ & $\begin{array}{c}\text { Kuning } \\
\text { pucat }\end{array}$ & $\begin{array}{l}\text { Tidak } \\
\text { berbau }\end{array}$ & \\
\hline $\begin{array}{c}\text { Formula II } \\
(0,5: 3)\end{array}$ & Kental & $\begin{array}{c}\text { Kuning } \\
\text { pucat }\end{array}$ & $\begin{array}{c}\text { Tidak } \\
\text { berbau }\end{array}$ & $\begin{array}{l}\text { Agak } \\
\text { kental }\end{array}$ & $\begin{array}{c}\text { Kuning } \\
\text { pucat }\end{array}$ & $\begin{array}{l}\text { Tidak } \\
\text { berbau }\end{array}$ & Memenuhi \\
\hline $\begin{array}{c}\text { Formula III } \\
(0,75: 4)\end{array}$ & Kental & $\begin{array}{l}\text { Kuning } \\
\text { pucat }\end{array}$ & $\begin{array}{c}\text { Tidak } \\
\text { berbau }\end{array}$ & $\begin{array}{c}\text { Agak } \\
\text { kental }\end{array}$ & $\begin{array}{c}\text { Kuning } \\
\text { pucat }\end{array}$ & $\begin{array}{l}\text { Tidak } \\
\text { berbau }\end{array}$ & Syarat \\
\hline
\end{tabular}

Tabel 5. Hasil pengamatan homogenitas sediaan hand sanitizer sebelum dan sesudah uji stabilitas dipercepat selama 6 siklus menggunakan alat climatic chamber.

\begin{tabular}{|c|c|c|c|c|}
\hline (Karbopol : Na.CMC) & $\begin{array}{l}\text { Sebelum } \\
\text { pengujian }\end{array}$ & $\begin{array}{l}\text { Sesudah } \\
\text { pengujian }\end{array}$ & Persyaratan & Hasil \\
\hline $\begin{array}{c}\text { Formula I }(0,25: 2) \\
\text { Formula II }(0,5: 3) \\
\text { Formula III }(0,75: 4)\end{array}$ & $\begin{array}{l}\text { Homogen } \\
\text { Homogen } \\
\text { Homogen }\end{array}$ & $\begin{array}{l}\text { Homogen } \\
\text { Homogen } \\
\text { Homogen }\end{array}$ & $\begin{array}{l}\text { Sediaan menunjukan susunan } \\
\text { yang homogen dan tidak } \\
\text { terlihat adanya butiran kasar }\end{array}$ & $\begin{array}{c}\text { Memenuhi } \\
\text { syarat }\end{array}$ \\
\hline
\end{tabular}

Tabel 6. Hasil pengamatan sineresis sediaan hand sanitizer sebelum dan sesudah uji stabilitas dipercepat selama 6 siklus menggunakan alat climatic chamber.

\begin{tabular}{|c|c|c|c|c|}
\hline (Karbopol : Na.CMC) & $\begin{array}{l}\text { Sebelum } \\
\text { pengujian }\end{array}$ & $\begin{array}{l}\text { Sesudah } \\
\text { pengujian }\end{array}$ & Persyaratan & Hasil \\
\hline Formula I (0,25 : 2) & $\begin{array}{l}\text { Tidak terjadi } \\
\text { sineresis }\end{array}$ & $\begin{array}{l}\text { Tidak terjadi } \\
\text { sineresis }\end{array}$ & $\begin{array}{l}\text { Sineresis terjadi jika } \\
\text { keluarnya air dari }\end{array}$ & \\
\hline Formula II $(0,5: 3)$ & $\begin{array}{l}\text { Tidak terjadi } \\
\text { sineresis }\end{array}$ & $\begin{array}{l}\text { Tidak terjadi } \\
\text { sineresis }\end{array}$ & $\begin{array}{l}\text { dalam gel sehingga } \\
\text { gel menggerut }\end{array}$ & $\begin{array}{l}\text { Memenuhi } \\
\text { syarat }\end{array}$ \\
\hline Formula III $(0,75: 4)$ & $\begin{array}{l}\text { Tidak terjadi } \\
\text { sineresis }\end{array}$ & $\begin{array}{l}\text { Tidak terjadi } \\
\text { sineresis }\end{array}$ & & \\
\hline
\end{tabular}

Tabel 7. Hasil pengukuran pH sediaan hand sanitizer sebelum dan sesudah uji stabilitas dipercepat selama 6 siklus menggunakan alat climatic chamber.

\begin{tabular}{ccccc}
\hline (Karbopol : Na.CMC) & $\begin{array}{c}\text { Sebelum } \\
\text { pengujian }\end{array}$ & $\begin{array}{c}\text { Sesudah } \\
\text { pengujian }\end{array}$ & Persyaratan & Hasil \\
\hline Formula I $(\mathbf{0 , 2 5}: \mathbf{2})$ & 5 & 5 & & Memenuhi \\
Formula II $(\mathbf{0 , 5}: \mathbf{3})$ & 5 & 5 & $4,5-6,5$ & syarat \\
Formula III $(\mathbf{0 , 7 5}: \mathbf{4})$ & 6 & 6 & & \\
\hline
\end{tabular}


Tabel 8. Hasil uji viskositas sediaan hand sanitizer sebelum dan sesudah uji stabilitas dipercepat selama 6 siklus menggunakan alat climatic chamber.

\begin{tabular}{ccccc}
\hline (Karbopol : Na.CMC) & $\begin{array}{c}\text { Sebelum } \\
\text { penyimpanan }\end{array}$ & $\begin{array}{c}\text { Sesudah } \\
\text { penyimpanan }\end{array}$ & Persyaratan & Hasil \\
\hline Formula I (0,25 : 2) & 4151 & 3557 & & Tidak memenuhi syarat \\
Formula II (0,5 : 3) & 3907 & 3137 & $2.000-$ & Memenuhi syarat \\
Formula III (0,75: 4) & 2993 & 2471 & $4.000 \mathrm{cP}$ & . \\
\hline
\end{tabular}

Tabel 9. Hasil pengukuran daya sebar sediaan hand sanitizer sebelum dan sesudah uji stabilitas dipercepat selama 6 siklus menggunakan alat climatic chamber.

\begin{tabular}{ccccc}
\hline (Karbopol : Na.CMC) & $\begin{array}{c}\text { Sebelum } \\
\text { pengujian }\end{array}$ & $\begin{array}{c}\text { Sesudah } \\
\text { pengujian }\end{array}$ & Persyaratan & Hasil \\
\hline Formula I (0,25 : 2) & $5 \mathrm{~cm}$ & $6,5 \mathrm{~cm}$ & & Memenuhi syarat \\
Formula II (0,5 : 3) & $5,5 \mathrm{~cm}$ & $7 \mathrm{~cm}$ & $5-7 \mathrm{~cm}$ & Memenuhi syarat \\
Formula III $(\mathbf{0 , 7 5}: \mathbf{4})$ & $4,7 \mathrm{~cm}$ & $7,5 \mathrm{~cm}$ & & Tidak memenuhi syarat \\
\hline
\end{tabular}

\section{PEMBAHASAN}

Pada penelitian ini telah dibuat sediaan hand sanitizer dengan menggunakan bahan aktif dari ekstrak Biji Pangi. Hal ini didasarkan pada penelitian Christine Makagansa yang dilakukan pada tahun 2015 yang menyatakan bahwa ekstrak akuades Biji Pangi memiliki kemampuan untuk menghambat pertumbuhan bakteri Staphylococcus aureus.(Christine Makagansa, Christine F. Mamuaja 2015).

Dalam penelitian ini, dibuat suatu sediaan hand sanitizer dari ekstrak Biji Pangi dengan menggunakan variasi konsentrasi basis Karbopol : Natrium CMC yaitu 0,25\%:2\% ; 0,5\%:3\% ; 0,75\%:4\%. Kombinasi Natrium CMC dan Karbopol berperan sebagai basis yang akan menghasilkan gel yang homogen dan konsistensi yang baik.(Tabibi 1990) Keuntungan penggunaan Natrium CMC sebagai basis gel diantaranya adalah memberikan viskositas stabil pada sediaan.(Tabibi 1990) Namun, penggunaan Natrium CMC sebagai basis gel dapat membentuk larutan koloida dalam air yang dapat membuat gel menjadi tidak jernih karena menghasilkan dispersi koloid dalam air yang ditandai munculnya bintik-bintik dalam gel.(Rowe et al. 2009). Selain itu, sediaan gel berbasis CMC-Na memiliki diameter penyebaran yang lebih kecil dibanding gel berbasis karbopol. Penambahan basis gel berupa karbopol diharapkan dapat memperbaiki kekurangan tersebut, sehingga gel yang dihasilkan menjadi jernih dan diharapkan memiliki daya sebar yang baik. Berdasarkan Rowe dkk (2006), kadar CMC-Na yang digunakan sebagai basis gel adalah 3-6\%, sedangkan karbopol adalah $0,5-2 \%$.

Selain Natrium CMC dan Karbopol sebagai basis, beberapa bahan yang digunakan sebagai bahan dasar dalam pembuatan hand sanitizer adalah TEA sebagai pengalkali, Gliserin sebagai pelembab, Metil Paraben sebagai pengawet.

Sediaan hand sanitizer dari ekstrak Biji Pangi ini dilakukan beberapa pengujian mutu fisik yakni stabilitas dipercepat pada suhu $40 \mathrm{C}$ selama 24 jam pertama dan suhu $400 \mathrm{C}$ pada 24 jam berikutnya dengan kelembapan tetap selama 6 kali siklus menggunakan alat climatic chamber dengan parameter yang diukur yaitu pengamatan organoleptis, uji homogenitas, uji sineresis, uji viskositas, pengukuran $\mathrm{pH}$ dan pengukuran daya sebar. Sediaan hand sanitizer dari ekstrak Biji Pangi dapat dinyatakan memenuhi syarat mutu fisik apabila sebelum dan sesudah pengujian memenuhi persyaratan yang telah ditetapkan.

Pengamatan organoleptis sediaan hand sanitizer dari ekstrak Biji Pangi meliputi konsistensi/bentuk, warna dan bau. Hasil data uji organoleptis pada ketiga formula yaitu dengan variasi konsentrasi basis Karbopol : Natrium CMC yaitu $0,25 \%: 2 \% ; 0,5 \%: 3 \% ; 0,75 \%: 4 \%$ sebelum penyimpanan berwarna kuning pucat, tidak berbau namun dengan konsistensi yang berbeda (Tabel 4).

Uji homogenitas merupakan salah satu uji yang penting dalam membuat formula sediaan Farmasetika, tujuannya adalah untuk mengetahui apakah bahan - bahan dalam formulasi tersebut tercampur secara merata atau tidak. Pengujian ini 
dilakukan untuk mengetahui bahwa zat aktif terdistribusi secara merata dalam sediaan dan tidak ada partikel yang menggumpal sehingga menghasilkan efek yang maksimal. Pengujian homogenitas ini dilakukan dengan cara sediaan dioleskan pada kaca trasparan dibawah cahaya. Ketiga formula sediaan hand sanitizer dari ekstrak Biji Pangi sebelum dan setelah penyimpanan menunjukkan homogenitas yang baik (Tabel 5).

Pengukuran $\mathrm{pH}$ bertujuan untuk mengetahui keasaman suatu sediaan terutama sediaan topical untuk menjamin sediaan gel tidak menyebabkan iritasi pada kulit. $\mathrm{pH}$ sediaan yang memenihi kriteria $\mathrm{pH}$ kulit yaitu dala interval 4,56,5.(Liu et al. 2010) Data hasil pengujian $\mathrm{pH}$ sediaan gel dari ekstrak Biji Pangi menunjukkan bahwa selama pengujian, ketiga formula tidak mengalami perubahan $\mathrm{pH}$ dan memenuhi persyaratan (Tabel VI).

Pengujian sineresis adalah pengujian untuk melihat peristiwa keluarnya air dari dalam sediaan hand sanitizer dimana fase gel akan mengkerut sehingga cenderung memeras air keluar dari dalam gel, akibatnya gel nampak lebih kecil dan padat. Sebelum dan setelah penyimpanan, ketiga formula tidak menunjukkan terjadinya sineresis (Tabel V).

Uji viskositas dilakukan untuk mengetahui nilai viskositas dari sediaan hand sanitizer yang dibuat. Hasil nilai viskositas yang diperoleh sebelum penyimpanan dari ketiga formula memenuhi syarat viskositas yang baik untuk sediaan topikal berbentuk gel yaitu 2.000 4.000 cPs. Setelah penyimpanan pada ketiga formula terjadi penurunan viskositas. Hal ini menunjukkan bahwa terjadi perubahan setelah penyimpanan. Berdasarkan Florence and Attwood tahun 1998 bahwa Karbopol memberikan pengaruh yang lebih besar terhadap viskositas dibandingkan dengan $\mathrm{Na} \mathrm{CMC}$ hal ini menunjukkan bahwa semakin besar proporsi carbopol yang digunakan akan meningkatkan respon viskositas, sebaliknya semakin besar proporsi $\mathrm{Na}$ CMC yang digunakan akan menurunkan respon viskositasnya. Dari persamaan tersebut ini dikarenakan pembentukan gel carbopol sangat tergantung pada proses ionisasi gugus karboksil, diduga pada $\mathrm{pH}$ asam, gugus karboksil pada struktur molekul carbopol tidak terionisasi. Apabila $\mathrm{pH}$ dispersi carbopol ditingkatkan dengan penambahan suatu basa, maka secara progresif gugus karboksil akan terionisasi. Adanya gaya tolak-menolak antara gugus yang terionkan menyebabkan ikatan hidrogen pada gugus karboksil meregang sehingga terjadi peningkatan viskositas. Meskipun demikian hasil dari uji viskositas 2 sediaan ini tetap memenuhi syarat, kecuali sediaan Formula I dengan konsentrasi karbopol 0,1\% dan Natrium CMC 2\% tidak memenuhi syarat (Tabel VII).

Pengujian daya sebar dilakukan untuk mengetahui kemampuan gel untuk menyebar pada lokasi pemakaian. Berdasarkan Tabel VIII, terjadi peningkatan daya sebar sediaan Hand sanitizer. Berdasarkan Fennema, Karen and Lund tahun 1996 bahwa Na CMC memberikan pengaruh yang lebih besar terhadap daya sebar dibandingkan dengan Karbopol, hal ini menunjukkan bahwa semakin besar proporsi Na CMC yang digunakan akan meningkatkan respon daya sebarnya, sebaliknya semakin besar proposi carbopol akan menurunkan respon daya sebarnya. Disamping karena viskositas yang lebih rendah, maka diameter penyebarannya semakin luas. Hal ini dikarenakan $\mathrm{Na} \mathrm{CMC}$ dihasilkan dari mereaksikan $\mathrm{NaOH}$ dengan selulosa murni, kemudian ditambahkan Na-kloro asetat. Meskipun pada F1,F2 dan F3 terjadi perunurunan daya sebar tetapi hasil yang didapatkan tetap memenuhi syarat.

Pada penelitian ini tidak dilakukan efektivitas dan daya hambat sediaan gel Hand sanitizer karena ketebatasan waktu, padahal pengujian efektivitas dan daya hambat penting dilakukan guna mengetahui pengurangan bakteri yang terdapat di tangan.

\section{KESIMPULAN}

Berdasarkan hasil penelitian yang telah dilakukan maka dapat disimpulkan bahwa :

1. Ekstrak Biji Pangi dapat diformulasikan menjadi sediaan gel dengan konsentrasi basis Karbopol : Natrium CMC yaitu 0,5\%:3\%.

2. formula gel dengan konsentrasi basis Karbopol : Natrium CMC yaitu 0,5\%:3\% memenuhi semua persyaratan mutu dan tetap stabil setelah disimpan dengan pengujian dipercepat.

\section{SARAN}

Disarankan untuk peneliti selanjutnya agar dapat melakukan penelitian lebih lanjut untuk mengetahui efektifitas atau daya hambat sediaan gel hand sanitizer dari ekstrak Biji Pangi (Pangium edule Reinw).

\section{UCAPAN TERIMA KASIH}

Ucapan terima kasih kepada Poltekkes Kemenkes Makassar yang telah memfasilitasi terlaksananya penelitian ini. 


\section{DAFTAR PUSTAKA}

Ali, Fahmi, Hendra Stevani, and Dwi Rachmawaty. 2019. "Formulasi dan Stabilitas Sediaan Body Scrub Bedda Lotong Dengan Variasi Konsentrasi Trietanolamin." Media Farmasi 15(1): 71.

Christine Makagansa, Christine F. Mamuaja, Lucia C. Mandey. 2015. "Kajian Aktivitas AntiBakteri Ekstrak Biji Pangi (Pangium Edule Reinw) Terhadap Staphylococcus Aureus, Bacillus Cereus, Pseudomonas Aeruginosa Dan Escherichia Coli Secara In Vitro." Ilmu dan Teknologi Pangan 3(1).

Fransin Mamuaja, Christine, and Frans Lumoindong. 2017. Jphpi Aktivitas Antimikroba Ekstrak Biji Kluwek (Pangium Edule) Sebagai Bahan Pengawet Alami Bakso Ikan Tuna.

Kementerian Kesehatan Republik Indonesia. 2018."Riskesdas."

http://www.depkes.go.id/article/view/18121 200001/prevent-prevent-and-prevent-thevoice-of-the-world-fight-diabetes.html.

Liu, Pengbo et al. 2010. "Effectiveness of Liquid Soap and Hand Sanitizer against Norwalk Virus on Contaminated Hands." Applied and environmental microbiology 76(2): 394-99. http://www.ncbi.nlm.nih.gov/pubmed/19933 337 (September 16, 2019).

Rowe, Raymond C., Paul J. Sheskey, Siân C. Owen, and American Pharmacists Association. 2009. Handbook of Pharmaceutical Excipients. APhA/Pharmaceutical Press.

Tabibi, S. Esmail. 1990. "Pharmaceutical Dosage Forms: Disperse Systems. Volume 2. Edited by Herbert A. Lieberman, Martin M. Reiger, and Gilbert S. Banker. Marcel Dekker: New York. 1989. $26 \times 18 \mathrm{~cm}$. Xx + 690pp. \$125.00." Journal of Pharmaceutical Sciences 79(9): 856.

World Health Organization. Patient Safety. WHO Guidelines on Hand Hygiene in Health Care : First Global Patient Safety Challenge Clean Care Is Safer Care. 